Research Report No. 31/2008

\title{
Institutional Transplant as Political Opportunity: The Practice and Politics of Indian Electricity Regulation
}

Navroz K. Dubash

Follow this and additional works at: http:/ / digitalcommons.osgoode.yorku.ca/clpe

\section{Recommended Citation}

Dubash, Navroz K., "Institutional Transplant as Political Opportunity: The Practice and Politics of Indian Electricity Regulation" (2008). Comparative Research in Law \& Political Economy. Research Paper No. 31/2008.

http://digitalcommons.osgoode.yorku.ca/clpe/202 


\section{Comparative Research in Law \& Political Economy}

Navroz K. Dubash

Institutional Transplant as Political Opportunity: The Practice and Politics of Indian Electricity Regulation

EDTTORS: Peer Zumbansen (Osgoode Hall Law School, Toronto, Director, Comparative Research in Law and Political Economy, York University), John W. Cioffi (University of California at Riverside), Lindsay Krauss (Osgoode Hall Law School, Toronto, Production Editor) 

CLPE Research Paper 31/2008

Vol. 04 No. 06 (2008)

\title{
Navroz K. Dubash
}

\section{Institutional Transplant as Political OpPoRTUnity: The Practice of INDIAN ELECTRICITY REgUlATION}

\begin{abstract}
India has a decade-long experience with independent regulatory agencies in public services as an institutional transplant from the industrialized world. Introduced at the behest of international donor agencies, regulators in India are intended, somewhat naively, to provide an apolitical space for decision making to assuage investor concerns over arbitrary administrative actions, and thereby stimulate private investment. In practice, regulators have had to negotiate a terrain over which the state has continued to exercise considerable control. Regulators have also been been shaped in their functioning by national and sub-national political traditions and by administrative and political practices. The result is a hybrid institutional form that combines politics as usual with intriguing new, and unanticipated, opportunities for political intervention.
\end{abstract}

This paper will explore the origins of electricity regulation as a form of institutional "isomorphism." It will then compare the regulatory experience in India's electricity sector across two Indian states to understand the implications of transplanting regulatory agencies in the global south. An examination of the process through which regulatory decisions are reached illustrates how existing bureaucratic and technocratic networks, transplanted procedures, and administrative cultures combine to conservatively manage long-standing political tensions around electricity. In seeking to manage those tensions, regulators often take decisions - on tariff setting, for example - based on a political reading that belies the technocratic narrative on which institutional credibility rests. At the same time, civil society groups ranging from residential associations to professional associations to individuals are using newly created regulatory spaces to structure a more deliberative decision process. 
Keywords: regulation, governance, electricity, isomorphism, deliberative democracy, India

JEL classification: G38, K23

\section{Author Contact:}

Navroz K. Dubash

Associate Professor, Centre for the Study of Law and Governance

Jawaharlal Nehru University, New Delhi

Email: ndubash@gmail.com 



\title{
INSTITUTIONAL TRANSPLANT AS POLITICAL Opportunity: The Practice and Politics of INDIAN ELECTRICITY REGULATION
}

\author{
Navroz K. Dubash ${ }^{*}$
}

\section{INTRODUCTION}

Independent regulatory agencies have entered India through the back-door, little remarked upon and even less understood. Proponents of regulatory bodies - notably donor agencies - view the mechanism as a way to insulate politics from decision making. Insiders to Indian government and administration, notably including some regulators and regulated, dismiss regulatory bodies as one more layer of government, barely distinguishable from preceding layers. In this paper, I suggest that regulation in India has certainly not fulfilled the naïve expectations of the designers, but that it has led to a process of re-making governance in India, opening doors to the construction of regulation as a new democratic space. My aim in this paper is to map out the contours of an emergent politics of regulation in India by looking at the case of electricity regulation.

By looking at India I also intend to contribute to what is currently a very thin literature on regulation in practice in the developing world, with the possible exception of Latin America. There are good reasons to believe that regulation in developing countries will have distinct features from that in either the United States, or the emergent regulatory state in Europe. Common features that shape regulatory outcomes in developing countries include the greater presence and authority of external actors, particularly donors, as vectors of policy transfer, the importance of consultants as knowledge carriers and as implementers, the overbearing but paradoxically also weak state, and the propensity for thin state legitimacy. From a practical perspective, states in the developing world are selfconsciously re-orienting themselves toward forms of steering over

\footnotetext{
* Associate Professor, Centre for the Study of Law and Governance, Jawaharlal Nehru University, New Delhi.
} 
ownership, without much reflection on whether and how this shift changes the nature of politics and concerns of democratic legitimacy and accountability. In the conclusion I reflect on some of these broader concerns that relate to regulation in the developing world.

My point of entry to regulation in India is the electricity sector. As a leading concern of economic reformers for over a decade, electricity is a good example of efforts to re-make a state-owned and controlled sector around the new vision of private ownership and arms-length regulation. In addition, electricity regulators in India have been established at the state level, allowing for comparison of different states with different political and other conditions, but within the same larger administrative culture and legal traditions. In this paper I examine electricity regulation in Andhra Pradesh, a state with a reputation as a successful reformer, and in Delhi, an early example of an effort to privatize electricity. My approach is considerably informed by Hancher and Moran's (1989) device of a "regulatory space," which seeks to focus attention on the institutional and political specificities of particular regulatory contexts.

The paper is divided into three sections. I begin with an exploration of how the establishment of Indian electricity regulators can be explained through sociological theories of institutional isomorphism. The next section turns to the two cases, Andhra Pradesh and Delhi, to examine both the macro- and micro-politics of regulatory agencies. A third section explores whether and how newly established regulatory agencies provide new spaces for democratic politics. I end with a concluding section that sketches the contours of regulatory space for Indian electricity, by drawing on the insights gained from the two cases.

\section{II. “ISOMORPHISM” IN INDIAN ELECTRICITY REGULATION}

The creation of independent regulatory agencies is often understood within the framework of a problem of delegation. Under what conditions, and why, would a government choose to delegate authority to an independent "non-majoritarian” body? Recent work suggests that a principal-agent 
framing of the problem of regulatory establishment is incomplete without attention to a more sociological understanding of regulatory origins. ${ }^{1}$ In this section, I lay out an explanation for the origins of Indian electricity regulation based on processes of institutional isomorphism, with attention to how regulators have become a way of signaling legitimacy within a larger project of restructuring and reform.

\section{A. The TANGLED LEgACY OF INDIAN ELECTRICITY}

Electricity is a "concurrent" subject under India's constitution, which places it under both central government and state government control. ${ }^{2}$ In 1948, the sector was organized around state-level, publicly owned and controlled State Electricity Boards (SEBs). SEBs were crafted in the crucible of post-independence India, and strongly shaped by the idea that electricity was a tangible and realizable benefit that the state could demonstrate to its citizens as a gain from achieving independence. In particular, SEBs had a dual nature as commercial entities and as instruments of development policy.

Since the SEBs effectively operated as extensions of the state Energy Ministries, they have been prey to a range of garden-variety, but crippling, problems of government in India. These span everything from internal markets for staff promotion and placement, to graft for non-payment of bills, to incorporation into the election financing apparatus.

Over time, the political fault lines in the sector have crystallized around three issues: farmers hanging on to populist subsidies, industrialists rebelling against the higher tariffs needed to support those subsidies, and increasingly affluent and mobilized urban consumers demanding better service. Meanwhile, finance ministries at state and central levels, backed by international donors, have given notice that budgetary subsidies to the sector must come to an end. By the early 1990s these oppositional forces had become clear; by the late 1990s they were crippling the performance of the sector.

\footnotetext{
${ }^{1}$ See, for example, Thatcher and Stone-Sweet (2002), and Gilardi (2004).

2 This section draws on Dubash and Rajan (2000), which reviews the recent political economy of India's electricity sector.
} 
State-level independent electricity regulatory commissions have been placed in the unenviable position of untangling these knots. In India, regulators have been created at both central and state levels, with the central regulator responsible for interstate issues, and state regulators with which I am concerned in this paper -- responsible for critical regulatory functions at the state level including tariff setting, establishing operating regulations and monitoring the sector.

\section{B. ElECtRICITY RESTRUCtURING AS A "RATIONALIZED MYtH”}

The steady decline of India's electricity sector during the late 1980s and early 1990s was coincident with a shift of seismic proportions in the global conventional wisdom around how best to organize the electricity sector. Electricity "restructuring" prescribes a transformation of publicly owned and managed monopoly electricity sectors into "unbundled" entities, subsequent privatization, and the introduction of competition between the newly created unbundled entities. ${ }^{3}$ Through the 1990s, this prescription, which originated in the UK and Chile, coalesced into a standard prescription for electricity sector reform, independent of national context. There is certainly some indication that the implications of this approach were inadequately thought through for sectors in countries such as India, where bread and butter management reforms were, and remain, arguably more important than a restructuring around competitive markets.

Independent regulatory agencies are an important piece of the larger restructuring prescription. In functional terms, they are intended to provide the means of regulating the residual monopoly segment of the "unbundled" electricity sector (the wires), establish and enforce the rules of market functioning, and set tariffs in the lead-up to competitive markets. Most significant, however, they are intended to excise politically determined, and therefore arbitrary, decision processes and replace them with technocratic, and hence predictable, decisions.

The quest for finances was an important part of the larger political context for the rapid rise of electricity restructuring. Emerging at a time of a larger global ideological shift toward the virtues of private investment, electricity

\footnotetext{
${ }^{3}$ Patterson (1999) provides a very readable introduction to the topic. Dubash and Singh (2005) critically review these ideas and locate the debate in Indian context.
} 
restructuring became the accepted precondition for attracting foreign investment.

Electricity restructuring, then, fits well Meyer and Rowan's (1977) description of rationalized myths as "rationalized and impersonal prescriptions that identify various social purposes as technical ones and specify in a rulelike way the appropriate means to pursue these technical purposes rationally.” Conformance to the restructuring agenda signaled seriousness and leant legitimacy to electricity policy reform.

\section{C. “ISOMORPHISM” IN THE INTRODUCTION OF INDEPENDENT REGULATORS}

The World Bank served as the dominant vector for transmission of the restructuring ideas to India. A 1993 policy statement made further lending for developing country electricity sectors conditional on progress toward a set of policies that included greater private sector involvement and establishment of independent regulators. As the policy put it: “...the Bank will require countries to set up transparent regulatory processes that are clearly independent of power suppliers and that avoid government interference in day-to-day power company operations” (World Bank 1993, p. 14). ${ }^{4}$

In the year the policy was issued, 1993, the World Bank brought that policy to India and explicitly invited states to take up the bargain. Five states initiated discussion, but only one state, Orissa, saw the process through in the form of corporatization, privatization, tariff reform and independent regulation (World Bank 1996). In its own statements, the World Bank clearly articulated the role of the regulator: “...to ensure the sustainability of tariff reform... inter alia to attract sufficient private investment and protect the interests of consumers” (World Bank 1996, p.7). A key contribution of the regulator to achieving these goals was "...to insulate Orissa's power sector from the government and ensure it's ...

\footnotetext{
${ }^{4}$ The other conditions -- commercialisation and corporatisation, importation of services, and encouragement of private investment - would soon become intertwined with the emergent model of competitive electricity markets emanating from the UK, to become a standard model of electricity restructuring applied to the developing world (Williams \& Dubash 2004).
} 
autonomy” (World Bank 1996, Annex 5.3, p. 2). In other words, the fundamental purpose of electricity regulation was to create an apolitical space for electricity decision, in large part to send a signal of credibility to investors. ${ }^{5}$

An army of donor funded consultants descended on Orissa to elaborate and assist implementation of this template, in a suggestion of what Powell and DiMaggio might label "normative isomorphism" associated with the entrenchment of a professional field. While donor and consultant led, the reforms could not fairly be described as entirely coerced; a substantial component of the political leadership and bureaucracy, including the thenChief Minister, supported a fundamental reform orientation. However, the role or value of independent regulation among these domestic "reformers" was not clear. In the opinion of an Indian consultant involved in the process, many officials saw regulation as a requirement of funding institutions or as a relatively costless diversionary tactic to signal seriousness about reform.

This narrative partially supports a view of the World Bank as an instrument of "coercive isomorphism" (DiMaggio and Powell 1991), transmitting both the regulatory form as a rationalized institution, and providing the motivation for adoption in the form of withdrawal of financing support in the case of non-compliance. It also suggests a role for consultants, notably of foreign origin, as agents of "normative isomorphism" through their professional status, which enabled them to confer legitimacy in the realm of electricity restructuring. However, as suggested above, there was also an element of willing adoption in the interests of buying and signaling legitimacy by state decision-makers, but only based on a larger perception that adoption of the model would make little difference to decisions on the ground. I return to this "decoupling" (Meyer and Rowan 1977) between institutional structures and work activities in a later section.

${ }^{5}$ The goal of insulation from political process led to interesting design debates. According to Indian consultants, foreign consultants were naïve about how to achieve this outcome. For example, it was at the insistence of Indian consultants that the Orissa reform act explicitly prohibited elected officials from ever assuming office as a regulator. 


\section{Regulation Extended: The Central Acts And "Mimetic ISOMORPHISM"}

The Orissa regulatory experiment was well short of being declared a success in its early years. In brief, regulatory "independence" quickly proved a double-edged sword: while the World Bank and state reformers expected the regulator to rapidly raise tariffs, the regulator instead decided that the public should not bear the burden of past mismanagement and decided on only a moderate increase. Regulatory attention to the political fall-out of tariff increases, while understandable and perhaps necessary, was certainly not what the original framers of Orissa's regulation were hoping for. Thus while the Orissa effort could have justifiably been read as the shifting of political contestation to a new political arena - the regulator - it was instead read as a less-than-desirable outcome driven by the idiosyncrasies of the individual regulators.

Despite these overtones of failure, at least with regard to the regulator's ability to signal credibility to investors, the Orissa approach to regulation has rapidly spread to other states. With state after state initiating plans for establishment of regulators - in most cases without the intervention of an external actor such as the World Bank -- the central government was faced with a possible proliferation of state acts under which regulatory bodies would be established. To provide some uniformity, the central (i.e. federal) government passed a central Electricity Regulatory Commissions Act (1998) to provide an alternative legal basis for state regulators, which was substantially based on the Orissa Act. Despite the Orissa experience to the contrary, the underlying presumption that it is indeed feasible to create an apolitical regulatory sphere simply by legislating one, was retained more or less intact.

In 2003, as part of a more comprehensive move toward an electricity sector based on competition, a national Electricity Act (2003) was passed, which embedded electricity regulators within a larger project of transition toward a competitive electricity market. The Electricity Act endowed regulators with a range of responsibilities including tariff setting, issuance of licenses, definition and enforcement of standards, promotion of renewable energy, and advisory functions with regard to competition and investment. The Act represented a culmination of a trend starting with 
Orissa, of devolving substantial powers away from the executive and toward regulators.

The rapid proliferation of independent electricity regulators across India and sanctioned by central legislation suggests isomorphism in a "mimetic" vein, an attempt to derive legitimacy in a context of uncertainty (DiMaggio and Powell 1991). That regulators proliferated even in the absence of any robust assessment of effectiveness, and in the face of a perception of early regulatory ineffectiveness, suggests that legitimacy derives less from effectiveness in outcome, than in a relatively impervious ratonalising myth around regulation.

\section{From Structure to Practice: INSTITUTIONAL CONTEXT AND THE EFFECTS OF "DECOUPLING"}

As Meyer and Rowan suggest, conformity with institutionalized myths can lead to gaps between institutional structure and ongoing practice, or a process of "decoupling." In this section I explore this decoupling effect by examining the practice of regulation in two of India's state: Andhra Pradesh (AP) and Delhi. In order to do so, however, it is necessary to explore the larger political context within which regulators are embedded. ${ }^{6}$ Recall that the kernel of the regulatory role, that which lends it legitimizing potential, is the purported ability to insulate from politics. Accordingly, I begin this section with a discussion of how regulation is shaped by the "macro-politics" in each state, before turning to the "micropolitics" of regulatory decision-making.

\footnotetext{
${ }^{6}$ Thatcher and Stone-Sweet (2002) draw attention to institutional context, particularly political leadership, as factors that mediate the pressure to delegate. While I emphasize the intentional delegation process somewhat less than do they, their reminder of the larger context is nonetheless significant.
} 
A. Macro-Politics: The Dominance of Politics as Usual

The larger context for electricity reform in India, and AP and Delhi are no exception, is the requirement for seismic, rather than incremental, change, along with an associated re-sorting of winners and losers. Not surprisingly, under these conditions, the extent of delegation of authority from governments to regulators, in practice, is limited.

Andhra Pradesh (AP) is widely considered the one case that bucks the general perception that politicians lack the "political will" for reform. At the time the regulator was established in 1999, the Chief Minister, Mr. Naidu, was firmly established as the leading light among state-level economic reformers and was heavily backed by the World Bank. Indeed, Andhra Pradesh rapidly became the poster child of reform for donor agencies.

At the time of reform, Andhra Pradesh faced a by-now familiar set of problems: high loss levels; abysmal monitoring of electricity use; threat of industrial flight from the grid; a work force potentially implicated in rentseeking; and weak and declining infrastructure quality. The context for reforms, including creation of a regulator, was one of stimulating and guiding a dramatic change in the sector. The solution devised by the consultants but endorsed, and vigourously so, by Naidu, rested on privatization of the sector and the introduction of competition as a necessary end.

As a prelude to privatization, the state owned system was subjected to bread and butter management improvements, such as new and improved monitoring systems, re-aligning staff incentives around performance, and striking a wage for results deal with labour. These measures were actively supported by the political leadership, symbolized by weekly meetings held between Mr. Naidu and the top management of the electricity utility, and yielded impressive results in terms of a turn-around in key outcome indicators.

However, the privatization effort was placed on hold, because of apprehensions that it would be politically unpopular in the 2004 state election, and because other state experiences - Delhi and Orissa - had 
garnered unfavourable publicity. In 2004, Mr. Naidu nonetheless lost the election, and privatization disappeared off the road map entirely. ${ }^{7}$

Regulation was, therefore, a necessary element in the reform scheme, but by no means the lynchpin. Indeed, Naidu viewed the regulator's role in quite circumscribed terms as being limited until competition began. By contrast to Orissa, where the state government was supportive but stepped back after the regulator was established, in AP the government was driving the implementation of reforms. Hence the regulator faced a less stern test; it did not have to be a gatekeeper against its own creators to nearly the same extent. Moreover, the responsibility for stewarding change did not lie with the regulator, but instead with the government, acting through the state utility. In Mr. Naidu's words, "government has to go for reform, not the regulator.",

The Delhi experience, by contrast, has entirely been dominated by the larger context of a high profile privatization in Delhi. Following the experience of Orissa, widely viewed as a failure, Delhi's attempt at privatization was a high stakes effort to get it right. The pressure has been enormous; failure in Delhi would reinforce a signal that privatization in Indian electricity is a hopeless cause, and cause investors to be even more wary of entering the country's electricity sector.

As in other states, the central objective of reform was to lower technical and, more important, commercial loss levels that together hovered above $50 \%$, and to improve service quality. The context within which the regulator was set was one of rapid and dramatic sectoral reform and change.

The privatization arrangements constructed by the government constrained the regulator in several ways. The regulator lost control over many of the standard regulatory tools: performance targets, the rate of return, and the ability to link tariffs and economic performance. Underlying this arrangement was a perceived need by the Delhi government for stability and predictability, especially in tariff setting, in order to reassure new private investors. The Delhi Electricity Regulatory Commission (DERC) vigorously protested the government's policy directive circumscribing its role, but to no avail. Ultimately, the Delhi regulator began its work with a

\footnotetext{
${ }^{7}$ Interview with consultant involved in AP reforms, 3/5/06.

${ }^{8}$ Interview with Mr. Naidu, former Chief Minister of AP, Hyderabad, 1/6/06.
} 
somewhat contentious relationship with the government, a shortened list of instruments with which to do its work, minimal experience and capacity, a highly charged political context, and two very powerful and sophisticated private companies to regulate.

In quite different ways, therefore, the two state experiences suggest that delegation to independent regulators as a means of "credible commitment" has little resonance. In AP, the government retained substantial control over decisions. In Delhi, while the government was far clearer about boundaries, and formally delegated some responsibilities, it did so within a highly truncated “zone of discretion” (Thatcher and Stone Sweet 2002).

\section{B. Micro-Politics And Institutional Decoupling}

If governments substantially retain control, how is the rationalizing myth of a technocratic regulator that ensures political insulation maintained? I suggest the answer lies in a better understanding of the micro-politics of regulation, and manner in which it facilitates decoupling of structure from outcome.

Three networks shape the internal organizational space of Indian electricity regulators: the Indian Administrative Service - the elite governmental bureaucracy, the technical electricity fraternity, and consulting firms. The combination of and balance between these three networks to a considerable extent shapes how the regulator mediates relationships with the government.

The IAS is a ubiquitous presence in electricity regulators; in 2003, ten of twenty one electricity regulators were drawn from the IAS (Prayas 2003). Dense IAS networks facilitate informal consultation and back-room decision. In addition, regulatory independence from the executive is challenging to pull off if regulators themselves come from a career administering political decisions. This tension is exacerbated when regulators are appointed directly from senior governmental positions, requiring them to shift, virtually over-night, from administering and defending government positions, to acting as an impartial referee. While it is by no means necessary that these pressures are entirely determinative, it is quite likely that the predominance of individuals from an IAS 
background curtail the space for emergence of a new and distinct regulatory culture.

The technical fraternity of India's public electricity utilities constitutes the second network that shapes the regulatory space. Emerging from over fifty years of state ownership, employees of state owned electricity utilities constitute the only available pool for staff, and for regulators with technical expertise. The dependence on public employees is reinforced by the regulator's human resource rules, which closely follow government scales and promotion criteria. The heavy representation of the technical fraternity within electricity regulators reinforces the image of the regulator as minimally distinct from the government. Finally, with a background operating within vertically integrated monopoly utilities, regulatory staff brings little knowledge of regulatory practice, let alone new trends in the organization of electricity such as introduction of competition and markets, ostensibly the rationale for transformation of the sector.

This shortfall is made up by consultants, who play a substantial role in regulation and constitute the third network that shapes regulation. Consultants are in many ways the intellectual change agents, and play the key role in translating broad policy directions into specific policy measures. The intellectual positions that inform consultants are informed by their typical background as recent business school graduates, with a smattering of ex-public sector employees, and are further developed and propagated through broader consultant networks.

Within the Andhra Pradesh regulator, decisions are shaped by interaction within the three components of regulators dominated by an IAS perspective, staff and consultants. Regulators use judicial metaphors to describe internal interactions. Consultants often prepare base materials on the request of the Commission, particularly on new policy matters such as performance based regulation. Commissioners then listen to the range of arguments before making a decision. Staff is often seen as representing the consumers' point of view and indeed, there is a separate section in each tariff order prepared exclusively by staff, independent from the Commission, which lays out a critical public perspective. Consultants typically represent and argue the "reform" view, which hews closely to the restructuring formula. Thus, the internal process appears to rest on dialogue, but ultimately filtered through an IAS perspective. 
The manner in which these internal arrangements lead to a form of institutional "decoupling" that allows the regulator to maintain a technocratic fiction is illustrated by an example of tariff setting.

The Andhra Pradesh regulator is statutorily empowered to independently set tariffs. In theory, this should be done by simply setting tariff to meet the revenue requirement of the utilities based on a given rate of return. Indeed, in its first year, the regulator had applied such a formula, leading to a steep tariff hike, which in turn led to substantial protests. In subsequent years, there are good indications that the regulator has been more circumspect, balancing the political realities of tariff hikes, the budget available for subsidies, and the requirements of financial health for the utilities. ${ }^{9}$ Specifically, the regulator has taken to setting an efficiency based "performance target" for the utilities to meet, which in many years obviates the need for a tariff increase. Doing so brings obvious political benefits to the government. In other words, the AP regulator has devised a means of side-stepping the straitjacket of technocratic procedure, even while framing its intervention - an efficiency enhancing performance target - within the larger narrative of technocratic decision-making, thereby facilitating a perception of regulatory independence from politics. Note that this approach is facilitated only because management reforms introduced by the AP government have provided the utility a reasonable amount of financial space. This space has allowed the regulator to play its balancing role without having to substantially transgress boundaries of either political or economic acceptability.

The Delhi case provides a similar example of decoupling, despite the more clearly articulated delegation enshrined in the privatization agreement. In one tariff setting exercise, a straight accounting of costs, returns and revenues would have required the regulator to approve a massive 35\% tariff increase. A hike of this scale would have been politically ruinous, particularly given a public perception that some of the private companies were failing to deliver on promises of service improvements. In response, the regulator, working with consultants, came up with the idea of creating a "regulatory asset" which allowed the tariff hike to be spread over future years. In subsequent years, a more modest $10 \%$ tariff hike led to public protest and an eventual roll-back of the tariff, confirming the regulator's political judgement.

${ }^{9}$ Interview with APERC staff, 26/5/06. 
Both these examples suggest that far from apolitical and technocratic regulation, Indian electricity regulators actively consider the political implications of their decisions, and, in order to accommodate politics, find creative ways of decoupling their decisions from the technocratic moorings of their institutional structures.

\section{A New Politics of Regulation?}

The de-coupling of regulatory structure from practice potentially opens interesting and creative new spaces for politics around electricity. ${ }^{10}$ With the presumption of one, correct, technocratic answer to regulatory decisions set aside, the door is left open for independent regulatory agencies to become new sites of politics around electricity. That these politics may potentially, at least, have a potential democratic nature is made possible by the enshrining in electricity regulators of administrative law procedures around transparency, participation, and recourse. ${ }^{11}$ In this section, I examine to what extent and how regulators have functioned as sites for democratic politics in AP and Delhi.

In AP, the regulator has established a procedural framework enabling access to information about the sector, a required process of public hearings in particular for tariff orders, and a mechanism for filing petitions and pleadings. For example, the Andhra Pradesh Electricity Regulatory Commission (APERC) has a well functioning and useful website, diligently holds hearings that are well attended, including in locations

\footnotetext{
${ }^{10}$ In his discussion of the rise of the regulatory state in Europe, Majone (1994) makes the point that procedural safeguards, such as public hearings, are an important part of building the legitimacy of a regulatory state. Prosser (1999) has perhaps developed this argument the farthest in his work on public utilities in the UK, elegantly arguing not only for procedural safeguards, but a form of reflexive proceduralism that examines the conditions under which participation provides necessary safeguards and regulatory legitimacy. Lodge (2004) catalogues and provides critical reflection on the instruments through which transparency and accountability can be facilitated, while Hira et. al. (2005) for an interesting cross-country empirical comparison of procedural measures in use in electricity regulation. See, also, Nakhooda, Dixit and Dubash (2007) for an attempt to develop and test indicators of regulatory governance across countries.

${ }^{11}$ I discuss the genesis of these procedures elsewhere (Dubash, 2008).
} 
outside the capital city, has translated regulatory materials into the local language, and has established an Advisory Committee including labor, agricultural and consumer representatives. All of these procedural changes constitute a sea change from the entirely non-transparent closed decisionmaking process under the pre-reform regime.

There remain, of course, some substantial holes in full implementation of the spirit of these procedures. For example, in one case the APERC convened a hearing on an issue only after substantial external pressure, and once it did so, issued a sixty page order the very next day, which clearly could not have incorporated insights from the hearing process (Electricity Governance Initiative - India, 2006). In addition, there remain grey areas on information disclosure, such as on investment plans, where the APERC has no clear policy and procedure, and by default withholds access to these materials. ${ }^{12}$ Hesitation and confusion on such matters has a great deal to do with the newness of the institution and its staffing by individuals who bring parochial and paternalistic attitudes characterized by former monopoly state utilities. There is little doubt, however, that under external pressure, the institutional space for regulatory governance is slowly but certainly becoming more open.

Regulatory procedures on information and participation have expanded the regulatory space in AP, to include labor groups, political parties, consumer groups, individual consumers, industry associations, farmers, and other public bodies such as municipalities. A scan of the tariff order for 2006-07 suggests that these opportunities are, in fact utilized. A total of 46 different individuals or institutions filed a total of 330 objections to the tariff orders of the three distribution companies in the state. ${ }^{13}$ Of these, 302 were "substantive" pertaining to issues that had to do with details of the tariff process, as compared to 28 "grievances" that were related to more narrow concerns that affected only the complainant or contained little or no substantive argumentation. Not surprisingly the largest number, 106, were by individual consumers, but substantial numbers of comments, in each case between 25 and 70, were filed by political parties (42), public entities

\footnotetext{
${ }^{12}$ This observation is based on a personal visit, during which the authors were allowed to open and view files on investment plans on the premises, but only after initial denial followed by a personal appeal to the Chairperson.

${ }^{13}$ Based on analysis conducted by the authors using data from tariff orders supplemented with information from APERC. This analysis excludes local language petitions, which are currently being translated.
} 
(28), industry (36), unions (68) and consumer organizations (43). Interestingly industrial buyers and others with deep pockets are not disproportionately represented in these comments.

While in some cases the comments reflect only a basic knowledge of the electricity sector and a nascent understanding of regulatory process, a handful of consistent interveners have won the respect of the Commission, being described as "almost equivalent to Commission staff in caliber". ${ }^{14}$ These regular and respected interveners are almost all from consumer groups, in some cases are individuals, rather than from industrial groups. Indeed, the latter were dismissed as narrow and parochial in their comments, rather than focusing on issues in a broader public interest. Respondents at the utility also express enthusiasm for consumer involvement, particularly in scrutinizing power purchase costs, which directly affect their own bottom line.

The flurry of public engagement stimulated by creation of the APERC has begun to re-shape regulatory politics at three levels. First, consumer groups have actively worked to broaden and deepen the procedural rules. For example, they have demanded hearings at district levels, requested and won local language translation of orders, and forced broader and transparent review of power purchase agreements.

Second, they have somewhat disrupted and injected themselves into the triangular negotiation between APERC, the Government and the utility. The main avenue for doing so is forcing release of information, and forcing public, documented, responses to raised objections, thereby limiting the extent to which adjustments in key parameters can be made behind the scenes. For example, farmer and consumer groups sought release of the agricultural census to measure rural power use conducted by the APERC. They have also sought and obtained public disclosure of the dispatch order of generating plants to ensure that one generator is not unfairly favoured over another.

Finally, they have achieved some substantive gains, most significantly in the area of power purchase and approval of new generating plant investment, which accounts for the majority of total electricity cost. ${ }^{15}$ Significantly, this is truly a public interest issue, as savings in power cost

\footnotetext{
${ }^{14}$ Interview with APERC, 2/5/06.

${ }^{15}$ Interview with senior management of APTransco, 19/5/06.
} 
accrue to all consumers, and cannot be captured by any single group. Gains in power purchase were achieved by forcing open the issue for debate before the regulator. In addition to arguments made by consumer groups, the resultant opportunities allow powerful actors such as the utility (for whom lower costs mean healthier finances) to pursue the issue to a greater extent than they otherwise would have. Indeed, in one case the process has led to strange bedfellows, with a petition jointly filed by the utility, the Peoples Monitoring Group on Electricity Regulation, and a journalist with Communist Party affiliation acting in his individual capacity. The expanded scope of regulatory governance has created new strategic opportunities for key actors in the sector.

The power purchase issue also illustrates how the APERC reacts to the various pressures it faces. In the case of one new generation plant, it withstood substantial pressure from the government, informally expressed, to considerably lower profit rates and therefore costs to consumers. ${ }^{16}$ In another case, faced with considerable government pressure, the regulator was arguably lax about ensuring adequate fuel supply for the plant, and in the process allowed the risk of fuel supply to be passed on to the consumer, potentially substantially hiking costs. ${ }^{17}$ The latter case is currently under further appeal. The implications of these two cases for the regulator's independence from versus control by the government rest in the details of each case. However, that these issues are debated, and that any gains are made at all, is almost certainly facilitated by public engagement and scrutiny.

The broadening of regulatory space to include consumers of all sorts, public interest groups, and media may yet be the most far reaching change brought about by independent regulation. While regulatory governance is at an early stage, the AP experience suggests that future developments will be well worth exploring.

In Delhi as in the Andhra Pradesh case, the statutory requirements for hearings, access to information and mechanisms of recourse have created an important new space for regulatory governance in Delhi. However, the weaknesses in the practical application of these procedural requirements are also considerable. For example, the DERC website is incomplete and

\footnotetext{
${ }^{16}$ Interview with APERC official, 1/5/06.

${ }^{17}$ Interview with citizen petitioner before APERC, 2/5/06, and with senior management of APTransco, 19/5/06.
} 
ill-organized, which along with the lack of an effective library or an organized index of documents makes accessing documents extremely difficult in practice. The hearings are not open to the public, but only to those who have submitted comments. This said, the wide availability of detailed tariff orders to the public, and the ability of consumers and interested parties of all sorts to present their views before the DERC, and obtain an answer from the distribution companies, represents an entirely new institutional space for public deliberation.

In 2004-05 the DERC received 212 objections to its tariff orders from 69 different objectors. ${ }^{18}$ Consumer groups or individuals accounted for about 40 of these while there were about 20 objectors from within industrial user groups. Of the total concerns expressed, by far the majority, (625 out of 683) were substantive complaints as compared to more narrow grievances.

By contrast to Andhra Pradesh, however, no small core of competent and knowledge intervenors had appeared to win the respect of the regulators. For example, DERC staff says they do not find public submissions helpful in improving the quality of tariff orders. And indeed the capacity base of intervenors is thin. Thus, the apex body of Delhi's Resident Welfare Associations (RWAs) which includes the wide spectrum of neighbourhoods, including well to do areas, files petitions based on patched together pieces of information, without deploying any resources to obtain specialized knowledge or skills. ${ }^{19}$ Similarly, the Chamber of Commerce hires a single consultant to write their comments, with little involvement or feedback from the staff, or mechanism of either quality control or ensuring that comments truly represent member interests. ${ }^{20}$

However, Delhi consumers are extremely active and skilled in the broader political arena around electricity. The apex body of RWAs skilfully uses the media to directly critique the companies and the DERC and to force engagement and consideration of their appeals at the highest political levels. While it is an effective tactic in the context of any particular skirmish, this approach has the effect of de-valuing and de-legitimizing the DERC as a forum for reconciling competing interests.

\footnotetext{
${ }^{18}$ Based on analysis conducted by the authors using data in DERC tariff orders.

${ }^{19}$ Interview with consumer representative, 20/1/06.

${ }^{20}$ Interview with Chamber of Commerce representative, 31/1/06.
} 
A political mapping of consumer voices in Delhi is also instructive and helps explain the emphasis on organized politics rather than on the DERC. The most vocal subgroup, the RWAs, speak for a distinct sub-section of Delhi's consumers self-identified as "middle class", but who include the top end of Delhi's income strata. They place themselves in opposition to small scale and illegal industry owned by local politicians and slum dwellings which contain those politicians vote banks. Both of these categories of consumers, they argue, receive free power at their expense. From this perspective, the DERC is relatively helpless; the problem and the solution, lies in the political process.

As a result of the dominance of the RWAs in the public discourse around electricity, the issues that have attained the highest profile in the DERC are questions of metering and billing and other consumer grievance issues, after an initial period when the DERC was seen to be non-responsive. Some of the upstream and more technically detailed matters also before the regulator, notably investment scrutiny, have tended to be ignored. Another important consequence is that voices of lower income groups and especially slum dwellers are seldom heard within the DERC process.

In sum, the effect of creating a new institutional space for regulatory governance has had relatively little beneficial effect on the regulatory process in Delhi. To the extent there are any substantive wins, they are on the issues closest to consumers - metering, billing and grievance redressal. The more significant observation is that, if anything, consumer action has by-passed the DERC, to re-focus attention on organized politics.

\section{CONCLUSION}

India is far from being a regulatory state in Majone's (1994) characterization of the shift from public ownership, planning and centralized administration to regulation through structuring of incentives and signals. Understood as an essential complement to privatization, regulation has persisted and multiplied even as efforts at privatization have ground to a near halt. Intended as a buffer against political forces to enable private participation, regulation has now become an end in itself, the most tangible expression of, or even a substitute for political reform. 
Thus constructed, electricity regulation in India risks being absorbed and accommodated within the existing political-bureaucratic system, with very little impact on decision making. The creation of separate agencies has introduced an element of transparency in decision making, but the impact of this is reduced by the embedding of the process within well worn networks. The signaling and credibility functions are muted by the overarching control of the political process. At root, the pattern of decision making in the sector is only transformed if there is a sustained political impetus to change. The only way beyond this dependence on the favourable alignment of larger political forces on a state by state basis is through re-conceptualizing regulation as a new political space, an intent quite removed from the original designers of electricity regulation. In other words, since the problem of electricity in India is at root a political problem - unchecked state control - the way out lies not in institutional design, but in the explicitly political solution of new, democratic and legitimate regulatory spaces.

The Indian electricity example also suggests considerable diversity in outcome at which two cases can only hint. It reinforces the importance of understanding historical timing, bureaucratic traditions and customs, and organizational attributes. In India, the story is particularly bound up with understanding the shifting nature of the state. An inductive approach to regulation would appear necessary to fully sketch out the character of regulatory spaces.

At the same time, the Indian experience does suggest some systematic influences that come into play when independent regulation is introduced to developing countries. I conclude this paper with a short discussion of two of these themes, which might be taken to the study of regulation in other parts of the developing world.

Attention to the role of donor agencies as vectors of institutional isomorphism may be a fruitful line of inquiry in many developing countries. The often uncritical acceptance of regulatory institutions as part of a package deal also comes with a lack of reflection on the role of regulation as a shaper of politics, other than the unchallenged assumption that regulation can make politics less relevant. That regulators are often introduced as part of donor driven and defined agendas may homogenize regulatory experience in some respects, and mute the impact of historical timing and geographic specificity. 
Finally, the Indian experience suggests that attention the potential for regulation to be conceived of as a new and democratic political space - is worth exploring. Regulatory governance in developing countries brings the challenge of weak and under-resourced civil society and possibly an over-bearing state with little regard for procedural safeguards. However, in the context of other weak and illegitimate public institutions, regulation has the benefit of being a newcomer without the baggage of the past. If the Indian example proves to be more generally true, the theoretical interest and normative contribution of regulation may well lie in its democratic potential. 


\section{REFERENCES}

Agarwal, Manish, Ian Alexander and Bernard Tenenbaum. 2003. The Delhi Electricity Discom Privatization: Some Observations and Recommendations for Future Privatization in India and Elsewhere. Washington DC: World Bank.

Ayres, I., and J. Braithwaite. 1992. Responsive Regulation: Transcending the Deregulation Debate. Oxford: Oxford University Press.

Braithwaite, John. 2005. Responsive Regulation and Developing Economics. Global Economic Governance Programme, University College, Oxford.

DiMaggio, Paul J., and Walter W. Powell. 1991 (1983). The Iron Cage Revisited: Institutional Isomorphism and Collective Rationality. In The New Institutionalism in Organizational Analysis, edited by W. W. Powell and P. J. DiMaggio. Chicago: University of Chicago Press.

Dubash, Navroz K. 2008. "Can Global Administrative Law Shape Local Political Opportunity Structures? A Study of Indian Electricity Regulators," Presented at a "Workshop on Global Regulatory Governance,” Organized by Centre for Policy Research New York University, New Delhi, January 5-6, 2008.

Dubash, Navroz K., and Daljit Singh. 2005. Alternating Currents: Introduction to an International Review of Electricity Restructuring. Economic and Political Weekly XL (50):5242-5248.

Dubash, Navroz K, and Sudhir Chella Rajan. 2000. Power Politics: Process of India's Power Sector Reform. Economic and Political Weekly XXXVI (35):3367-3390.

Electricity Governance Initiative - India. 2006. “Electricity Sector Governance in India: An Analysis of Institutions and Practice.” Centre for Policy Research, February 2006.

Fabrizio Gilardi. 2004. "Institutional Change in Regulatory Policies: Regulation through Independent Agencies and the Three New Institutionalisms." In The Politics of Regulation: Institutions and 
Regulatory Reforms for the Age of Governance, edited by Jacint Jordana andDavid Levi-Faur, Cheltenham, UK: Edward Elgar.

Hancher, and M. Moran. 1989. Organizing Regulatory Space. In Capitalism, Culture and Economic Regulation, edited by L. H. a. M. Moran: Clarendon Press.

Hira, Anil, David Huxtable, and Alexandre Leger. 2005. Deregulation and Participation: An International Survey of Participation in Electricity Regulation. Governance: An International Journal of Policy, Administration, and Institutions 18 (1 (January)):53-88.

Indian Express. 2005. RWAs Call for Rollback of Power, Water Tariff Hike. The Indian Express. August 7.

Levy, Brian, and Pablo T. Spiller. 1994. The Institutional Foundations of Regulatory Commitment: A Comparative Analysis of Telecommunication Regulation. Journal of Law, Economics, \& Organization 10 (2):201-246.

Lodge, Martin. 2004. Accountability and Transparency in Regulation: Critiques, Doctrines and Instruments. In The Politics of Regulation: Institutions and Regulatory Reforms for the Age of Governance, edited by J. Jordana and D. Levi-Faur. Cheltenham: Edward Elgar Publishing Limited.

Majone, Giandomenico. 1994. The Rise of the Regulatory State in Europe. West European Politics 17 (3):77-101.

Meyer, John W. and Brian Rowan. 1991 (1977). "Institutionalized Organizations: Formal Structure as Myth and Ceremony.” In The New Institutionalism in Organizational Analysis, edited by Walter W. Powell and Paul J. DiMaggio, Chicago: University of Chicago Press.

Moran, Michael. 2002. Understanding the Regulatory State. British Journal of Political Science 32:391-413 (1-24).

Morgan, Bronwen and Karen Yeung. 2007. An Introduction to Law and Regulation: Text and Materials. Cambridge University Press.

Patterson, Walt. 1999. Transforming Electricity. London: Earthscan. 
Posner, Richard A. 1974. Theories of Economic Regulation. The Bell Journal of Economics and Management Science 5 (2 (Autumn)):335-358.

Prayas. 2003. A Good Beginning But Challenges Galore. Pune: Prayas. Available at www.prayaspune.org.

— 2006. A Critical Review of the Performance of Delhi's Privatized Distribution Companies and the Regulatory Process. Pune: Prayas. Available at www.prayaspune.org.

Prosser, Tony. 1999. Theorising Utility Regulation. The Modern Law Review 62 (2 (March)):196-217.

Roy, Subhajit. 2005. Hike Out; Govt. Discoms to Share 10\% Burden. The Indian Express. July 24.

Stigler, George J. 1971. The Theory of Economic Regulation. The Bell Journal of Economics and Management Science 2 (1 (Spring)):321.

Thatcher, Mark. 2002. Delegation to Independent Regulatory Agencies: Pressures, Functions and Contextual Mediation. West European Politics 25 (1):125-147.

Thatcher, Mark, and Alec Stone Sweet. 2002. Theory and Practice of Delegation to Non-Majoritarian Institutions. West European Politics 25 (1):1-22. Williams, James H., and Navroz K. Dubash. 2004. Asian Electricity Reform in Historical Perspective. Pacific Affairs 77 (3):411-436.

World Bank. 1993. The World Bank's Role in the Electric Power Sector. Washington D.C.: The World Bank. 1996. Staff Appraisal Report: Orissa Power Sector Restructuring Project. Washington DC: World Bank. 